\title{
PREGNANCY-ASSOCIATED GLYCOPROTEIN CONCENTRATIONS IN NON-PREGNANT COWS: A CASE STUDY
}

\author{
A. Ayad ${ }^{1}$, K. Touati ${ }^{2}$ \\ ${ }^{1}$ University of Bejaia \\ Bejaia, 06000, Algeria \\ ${ }^{2}$ University of Liege \\ Liege, 4000, Belgium \\ hanine06@gmail.com
}

\begin{abstract}
The aim of the present work was undertaken to describe three cases of the bPAG concentration measure by three RIA systems during the post-partum period in non-pregnantcow. Three HolsteinFriesian cows of mixed age and parity were diagnosed as non-pregnant. Blood samples were removed from the coccygeal vessel into EDTA-coated tubes. Samples were collected every 2 days during a stabling period of two months in the absence of males. Plasma was obtained by centrifugation immediately after collection and was stored at $-20{ }^{\circ} \mathrm{C}$ until assay. Plasmatic PAG concentration was measured by radioimmunoassay technique with some modifications. In RIA-780 and RIA-809, there were high peak of PAG concentration that reached $2.56 \mathrm{ng} / \mathrm{ml}$ and $0.89 \mathrm{ng} / \mathrm{ml}$, respectively. These peaks lasted longer than 3 days (two successive samples were positive). The other RIA systems gave the values of PAG concentrations below cut-off of pregnancy diagnosis $(>0.8 \mathrm{ng} / \mathrm{ml}$ ) and remains always non-pregnant. Our data shows clearly that there is another source of glycoproteins expression (e.g. ovarian) apart from the placenta in cow. The present study could be a field for future larger studies on the same subject by exploring deeply other extra structures placental.
\end{abstract}

Key words: PAG, radioimmunoassay, non-pregnant, cow

\section{INTRODUCTION}

The pregnancy-associated glycoproteins (PAG) constitute a large family of glycoproteins specifically expressed in the outer epithelial cell layer (chorion/trophectoderm) of the placenta in eutherian species $[1,2]$. They are members of the aspartic proteinase (AP) family having high sequence homology to each other as well as with pepsin, pepsinogen, chymosin, cathepsin $\mathrm{D}$ and $\mathrm{E}$ and renin $[3,4]$.

The molecular biology researches estimated that cattle, sheep, and most probably all ruminants possess many, possibly 100 or more, PAG genes [1, 5]. The investigations have also demonstrated that different PAG cDNA are not expressed coordinately throughout pregnancy $[1,6]$. Some, for example, are expressed early, others only when pregnancy progresses.

Radioimmunoassay for PAG detection in serum or plasma samples is currently used as a specific serological method for pregnancy diagnosis in cattle from days 28 [7] to $30[8,9]$ after breeding, with a threshold level for pregnancy of $0.8 \mathrm{ng} / \mathrm{ml}$ [7].

The present study was undertaken to describe three cases of the bPAG measurement by different radioimmunoassay systems during the post-partum period in three nonpregnant cows from condition of stabling period and the absence of males. 


\section{MATERIALS AND METHODS}

Three Holstein Friesian cows ( $\mathrm{N}^{\circ} 7927,7678$ and 5279) of mixed age and parity were diagnosed as non-pregnant by PAG RIA-497 analysis. These females were checked by a mean of ultrasonography (Concept/MCV equipped with a 7.5 MHz Linear array, Dynamic Imaging Limited, Livingston, UK) and rectal exploration by the same veterinary.

Blood samples $(7.5$ to $9.0 \mathrm{ml}$ ) from non-pregnant females were removed from the coccygeal vein or artery into EDTA-coated tubes (Sarstedt, Numbrecht, Germany). Samples were collected every two days for 2 months. Plasma was obtained by centrifugation $(1,500 \times g$ for $15 \mathrm{~min})$ immediately after collection and stored at $-20^{\circ} \mathrm{C}$ until assay.

As regards the ethical aspects, the experimental procedure was performed completely in vitro except for blood sampling of the animals, which was performed according to good veterinary practice.

Bovine PAG 67kDa preparation (boPAG ${ }_{67}$; Accession number A61232) was used as standard and tracer for all assays [10]. The iodination $\left(\mathrm{Na}-\mathrm{I}^{125}\right.$, Amersham Pharmacia Biotech, Uppsala, Sweden) was carried out according to the Chloramine T method [11].

Antisera were raised in rabbits immunized $(\mathrm{R} \#)$ against different $\mathrm{PAG}$ preparations according to the technique of Vaitukaitiset [12]: R\#497 was raised against boPAG ${ }_{67}$ [13]; $\mathrm{R} \# 780$ was raised against ovPAG ${ }_{57+59}$ [14]; R\#809 was raised against ovPAG ${ }_{55}$ [15].

The measurement of plasma PAG concentrations was carried out by three distinct RIA systems (RIA-497, RIA-780 and RIA-809) differing in theantiserum, as described previously [16]. Briefly, standard and plasma samples $(0.1 \mathrm{~mL})$ were diluted respectively in $0.2 \mathrm{~mL}$ and $0.3 \mathrm{~mL}$ of Tris-BSA buffer.

The standard curve ranged from $0.2 \mathrm{ng} / \mathrm{ml}$ to $25 \mathrm{ng} / \mathrm{ml}$. In order to minimize nonspecific interference of plasma proteins, $0.1 \mathrm{ml}$ virgin heifer serum was added to each tube of the standard curve. After the addition of appropriate dilution of antisera $(0.1 \mathrm{ml})$, the serum samples and the standard tubes were incubated overnight at room temperature $\left(20-22^{\circ} \mathrm{C}\right)$. The following day, $0.1 \mathrm{ml}$ of $\mathrm{I}^{125}-\mathrm{PAG}(\approx 25.000 \mathrm{cpm})$ was added and the tubes were incubated for 4 hours at room temperature.

After the tubes had been incubated for $30 \mathrm{~min}$ at room temperature with $1.0 \mathrm{ml}$ the second antibody, a volume $2.0 \mathrm{ml}$ of Tris-BSA buffer was added and the tubes were centrifuged $(20 \mathrm{~min}$ at $1,500 \times \mathrm{g})$. The supernatant was aspirated, and a second wash was done with $3.0 \mathrm{ml}$ of Tris-BSA buffer. After centrifugation $(20 \mathrm{~min}$ at 1,500 $\times \mathrm{g})$, the tubes were aspirated and the pellet containing the ${ }^{125} \mathrm{I}-\mathrm{PAG}$ bound to the antibodies was counted using a gamma counter (LKB Wallac 126 Multigamma counter, Turku, Finland).

The minimal detection limit (MDL) calculated for RIA-497, RIA-780 and RIA-809 systems were $0.20 \mathrm{ng} / \mathrm{ml}, 0.18 \mathrm{ng} / \mathrm{ml}$ and $0.16 \mathrm{ng} / \mathrm{ml}$, respectively. Concerning the reproducibility of the five RIA systems, the intra-assay coefficients of variation RIA-497, RIA-780 and RIA-809 were 3.5\%, 6.1\% and 10.6\%, respectively. For the inter-assay coefficient of variation were $6.8 \%, 14.4 \%$ and $20.8 \%$, respectively. 
Assay pregnancy associated glycoprotein concentrations were performed in laboratory of endocrinology and animal reproduction in Liege (Faculty of Veterinary Medicine, University of Liege, Belgium).

Statistical analyses were carried out in STATVIEW (Version 4.55). The PAG concentrations measured in the non-pregnant cows were used to calculated mean $\pm \mathrm{SE}$.

\section{RESULTS AND DISCUSSION}

The PAG concentrations (mean $\pm \mathrm{SE}$ ) determined in plasma samples from nonpregnant $(n=3)$ during two months of observation are presented in Table 1 . In three cows, mean PAG concentrations measured by RIA-497 remained under the $0.8 \mathrm{ng} / \mathrm{ml}$ threshold used for pregnancy diagnosis (maximal concentrations of $0.57 \mathrm{ng} / \mathrm{ml}$ ).

Table 1

PAG concentrations (mean \pm SE) obtained by three PAG-RIA systems in three non-pregnant cows during the period observation.

Minimal and maximal values $(\mathrm{ng} / \mathrm{ml})$ are indicated in parenthesis

\begin{tabular}{|l|c|c|c|}
\hline \multicolumn{4}{|c|}{ PAG concentration $(\mathrm{ng} / \mathrm{ml})$} \\
\hline & RIA-497 & RIA-780 & RIA-809 \\
\hline Cow 7927 & $0.20 \pm 0.00$ & $0.39 \pm 0.06$ & $0.18 \pm 0.02$ \\
$(n=31)$ & $(0.20-0.20)$ & $(0.16-2.56)$ & $(0.18-0.31)$ \\
Cow 5227 & $0.20 \pm 0.00$ & $0.17 \pm 0.02$ & $0.20 \pm 0.04$ \\
$(n=31)$ & $(0.20-0.20)$ & $(0.16-0.47)$ & $(0.18-0.89)$ \\
Cow 7678 & $0.22 \pm 0.03$ & $0.33 \pm 0.25$ & $0.19 \pm 0.01$ \\
$(n=31)$ & $(0.20-0.57)$ & $(0.16-1.69)$ & $(0.18-0.29)$ \\
\hline
\end{tabular}

In RIA-780 and RIA-809, there were high peaks of PAG concentration that reached $2.56 \mathrm{ng} / \mathrm{ml}$ and $0.89 \mathrm{ng} / \mathrm{ml}$, respectively. These peaks lasted for duration longer than 3 days in cows 7927 and cow 7678 (Fig. 1 and Fig. 2, respectively). As well, we observed alone high PAG concentration determined by RIA-809 system above level of positive (0.89 ng/ml) in cow 5279 (Fig. 3).

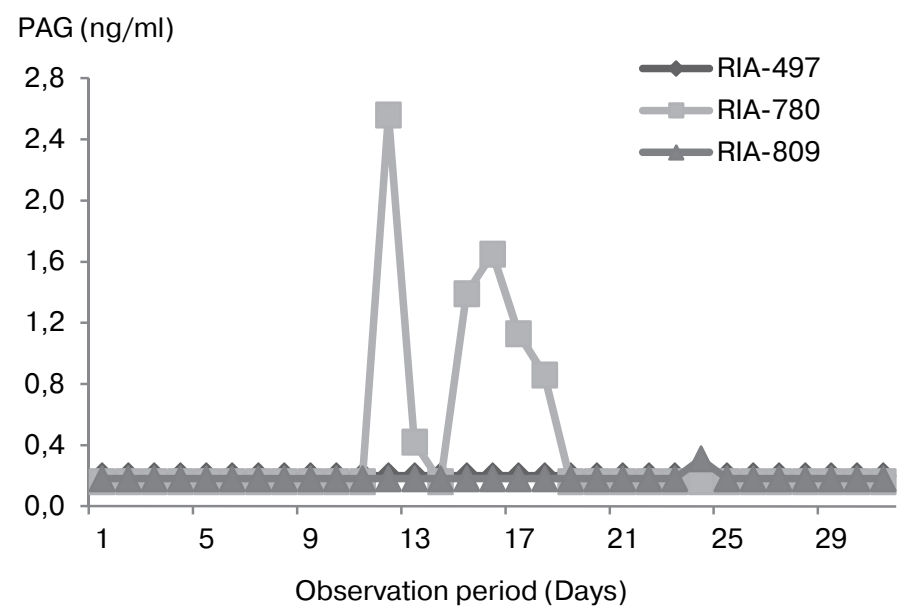

Fig. 1. Plasma concentrations of PAG $(\mathrm{ng} / \mathrm{ml})$ measured by three PAG-RIA systems during the period post-partum in cow 7927 


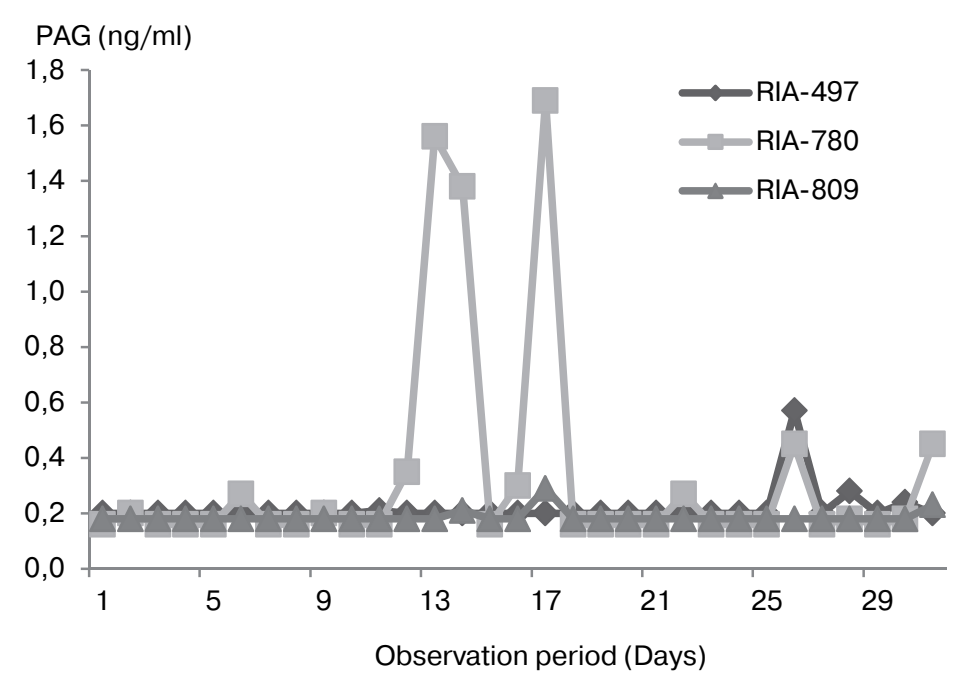

Fig. 2. Plasma concentrations of PAG $(\mathrm{ng} / \mathrm{ml})$ measured by three PAG-RIA systems during the period post-partum in cow 7678

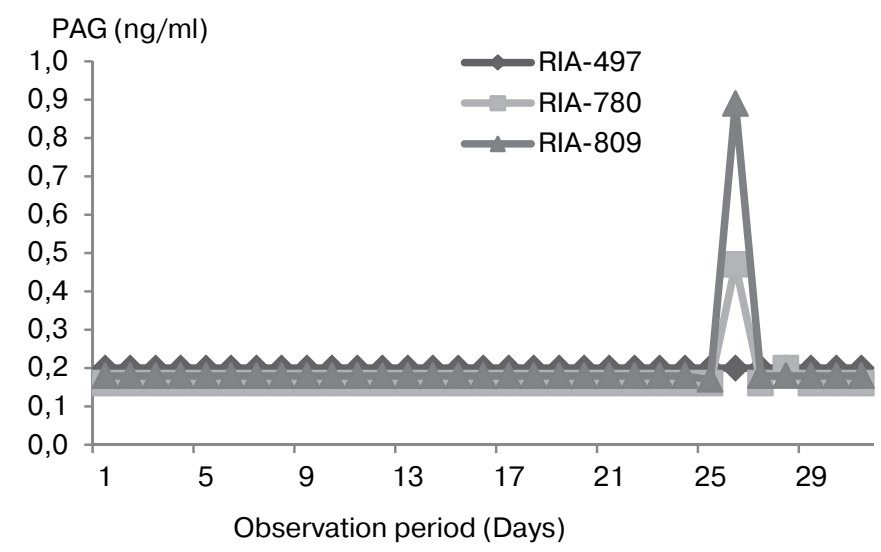

Fig. 3. Plasma concentrations of PAG $(\mathrm{ng} / \mathrm{ml})$ measured by three PAG-RIA systems during the period post-partum in cow 5279

In human and various animal species, a number of hormones and proteins appear in the maternal circulation by different party of reproduction tracts (e.g. maternal ovary). Many of these molecules are fetal-placental origin more than of maternal origin [17].

A long time ago, a research team identified a new protein from sera of pregnant women that was later purified from extracts of full-term placenta [18]. This placental protein, named pregnancy-specific (SP1), was considered to have no analog in the nonpregnant adult and to be strictly specific to the placenta. However, further studies have shown that the glycoprotein is not restricted to placenta or even to pregnant women.

Equal, glycoproteins expressed in the ruminant placenta have been isolated and characterized during the last three decades: PSPB [19]; Pregnancy-associated glycoproteins PAG; (PAG I ${ }_{67}$, bovPAG 1) [10]. Several ovPAG have been purified from 100 Dayovine placental [5], as well as from cotyledonary tissue collected between Day 60 
to 100 [15] and after Day 100 of pregnancy [14]. Caprine PAG showed high sequence identity (from 30 to $81 \%$ ) with proteins of the aspartic proteinase family like boPAG1, ovPAG1 and boPAG2 [20].

Molecular biology investigations showed that there are probably mores 100 PAG genes in ruminant genome [5] most of them being expressed in the superficial layers of the placenta. The conclusions by molecular biology explain also, that during certain stages of pregnancy some PAGs were expressed, whereas others were absent [1].

In this investigation, the RIA systems of PAG measurement were based of antisera raised against various PAG molecules differing in their molecular masses and species origin (bovine and ovine).

All non-pregnant cows were under condition of stabling period and the absence of males. As shown table 1, the PAG concentrations obtained by the use of RIA-497 system during the period of observation were normal values with minimal and maximal concentration below of threshold $0.8 \mathrm{ng} / \mathrm{ml}(0.20 \mathrm{ng} / \mathrm{ml}$ and $0.57 \mathrm{ng} / \mathrm{ml}$, respectively). The results presented here are in agreement with the authors' previous finding [13], in which the same RIA systems were used to measure PAG concentrations in plasma samples collected.

Concerning both RIA systems heterologous (RIA-780 and RIA-809), some the PAG concentrations obtained exceeded the level of positivity $(>0.8 \mathrm{ng} / \mathrm{ml})$ in three cows, which really does not correspond to the state of reproduction in experimental cows (i.e. post-partum period)

The period of observation of the cows exceeded 100 days after parturition [13]. The presence of the PAG concentrations in maternal blood could be explained by another extra-placental origin of secretion proteins (e.g. ovary). Knowing that the females were old, i.e. cows of reform, their ovaries could be at the origin of molecules secretions by the presence of new structures ovarian such as a prolonged luteal phase and the presence of a luteal cyst. Besides, in abstract Zoliet [19] reached to same observations which the antigen immunologically similar to boPAG67 has also been demonstrated in testicular tissue and an ovarian extract justifying the objective associated and not specific given to this glycoprotein. The explanation of PAG concentrations in plasma might be found in the fact exogenous proteinsmolecular express are recognized by both heterologous tests.

In conclusion, the data of the present report shows differences RIA systems when plasma issued from pregnant females were tested over a long period of observation. Likewise, our results show clearly that there is another source of glycoproteins expression apart from the placenta in cow. The present study could be a field for future larger studies on the same subject by exploring deeply other extra structures placental.

\section{ACKNOWLEDGEMENT}

Dr. A. Ayad wishes to thank Professor J.F. Beckers (Laboratory of Physiology of Animal Reproduction, Faculty of Veterinary Medicine, ULg, Belgium) for furnishing of reagents, technical assistance and reception in his laboratory. The authors thank Dr.C. Harrats (U. of Mostaganem, Algeria) for assistance with the English correction. 


\section{COMPETING INTERESTS}

The authors declare that they have no competing interests.

\section{REFERENCES}

1. Green JA, Xie S, Quan X, Bao B, Gan X, Mathialagan N, et al. Pregnancy-associated bovine and ovine glycoproteins exhibit spatially and temporally distinct expression patterns during pregnancy. Biology of reproduction. 2000; 62(6):1624-1631.

2. Zoli AP, Demez P, Beckers JF, Reznik M, Beckers A. Light and electron microscopic immunolocalization of bovine pregnancy-associated glycoprotein in the bovine placentome. Biology of Reproduction. 1992; 46(4):623-629.

3. Guruprasad K, Blundell TL, Xie S, Green J, Szafranska B, Nagel RJ, et al. Comparative modelling and analysis of amino acid substitutions suggests that the family of pregnancyassociated glycoproteins includes both active and inactive aspartic proteinases. Protein Engineering, Design and Selection. 1996; 9(10):849-856.

4. Xie S, Low BG, Nagel RJ, Kramer KK, Anthony RV, Zoli AP, et al. Identification of the major pregnancy-specific antigens of cattle and sheep as inactive members of the aspartic proteinase family. Proceedings of the National Academy of Sciences. 1991; 88(22):10247-10251.

5. Xie S, Green J, Bao B, Beckers JF, Valdez KE, Hakami L, et al. Multiple pregnancy-associated glycoproteins are secreted by day 100 ovine placental tissue. Biology of Reproduction. 1997; 57(6):1384-1393.

6. Hughes AL, Green JA, Garbayo JM, Roberts RM. Adaptive diversification within a large family of recently duplicated, placentally expressed genes. Proceedings of the National Academy of Sciences. 2000; 97(7):3319-3323.

7. Szenci O, Beckers J-F, Humblot P, Sulon J, Sasser G, Taverne M, et al. Comparison of ultrasonography, bovine pregnancy-specific protein $\mathrm{B}$, and bovine pregnancy-associated glycoprotein 1 tests for pregnancy detection in dairy cows. Theriogenology. 1998; 50(1):77-88.

8. Humblot P, Camous S, Martal J, Charlery J, Jeanguyot N, Thibier M, et al. Diagnosis of pregnancy by radioimmunoassay of a pregnancy-specific protein in the plasma of dairy cows. Theriogenology. 1988; 30(2):257-267.

9. Garth Sasser R, Ruder CA, Ivani KA, Butler JE, Hamilton WC. Detection of pregnancy by radioimmunoassay of a novel pregnancy-specific protein in serum of cows and a profile of serum concentrations during gestation. Biology of Reproduction. 1986; 35(4):936-942.

10. PagnahZoli A, Beckers J-F, Wouters-Ballman P, Closset J, Falmagne P, Ectors F. Purification and characterization of a bovine pregnancy-associated glycoprotein. Biology of Reproduction. 1991;45(1):1-10.

11. Greenwood FC, Hunter WM, Glover J. The preparation of 131I-labelled human growth hormone of high specific radioactivity. Biochemical journal. 1963;89(1):114.

12. Vaitukaitis J, Robbins J, Nieschlag E, Ross G. A method for producing specific antisera with small doses of immunogen. The Journal of Clinical Endocrinology \& Metabolism. 1971; 33(6):988-991.

13. Zoli AP, Guilbault LA, Delahaut P, Ortiz WB, Beckers JF. Radioimmunoassay of a bovine pregnancy-associated glycoprotein in serum: its application for pregnancy diagnosis. Biology of Reproduction. 1992; 46(1):83-92.

14. El Amiri B, Remy B, Sousa NM, Joris B, Ottiers NG, Perenyi Z, et al. Isolation and partial characterization of three pregnancy associated glycoproteins from the ewe placenta. Molecular Reproduction and Development: Incorporating Gamete Research. 2003; 64(2):199-206.

15. El Amiri B, Remy B, De Sousa NM, Beckers JF. Isolation and characterization of eight pregnancy-associated glycoproteins present at high levels in the ovine placenta between day 60 and day 100 of gestation. Reproduction Nutrition Development. 2004; 44(3):169-181.

16. Ayad A, Sousa N, Sulon J, Iguer-Ouada M, Beckers JF. Comparison of five radioimmunoassay systems for PAG measurement: ability to detect early pregnancy in cows. Reproduction in domestic animals. 2007; 42(4):433-440. 
17. Chard T. Pregnancy protein in the human. Biological and clinical significance. In: Hau J. (ed.) Pregnancy proteins in animals. Berlin: Walter de Gruyter; 1986. p. 9-20.

18. Tatarinov YS, Masyukevich VN. Immunochemical identified of new beta-l-globulin in blood serum of pregnant women. Bull. Eksp. Biol. Med. 1970; 69: 66-68. (In Russ).

19. Butler J, Hamilton W, Sasser R, Ruder C, Hass G, Williams R. Detection and partial characterization of two bovine pregnancy-specific proteins. Biology of Reproduction. 1982; 26(5):925-33.

20. Garbayo JM, Remy B, Alabart JL, Folch J, Wattiez R, Falmagne P, et al. Isolation and partial characterization of a pregnancy-associated glycoprotein family from the goat placenta. Biology of reproduction. 1998; 58(1):109-15.

\title{
INFORMATION ABOUT AUTHORS
}

Ayad Abdelhanine - Professor (DVM, MSc, PhD), Department of Biological Sciences of Environment, Faculty of Life and Nature Sciences, University of Bejaia. E-mail: hanine06@gmail.com, abdelhanine.ayad@univ-bejaia.dz

Touati Kamal — Surgery for Large Animals, Faculty of Veterinary Medicine, University of Liege, Belgium.

\section{For citation:}

Ayad A, Touati K. Pregnancy-associated glycoprotein concentrations in non-pregnant cows: a case study. RUDN Journal of Agronomy and Animal Industries, 2018, 13 (4), 287-293. doi: 10.22363/2312-797X-2018-13-4-287-293.

DOI: 10.22363/2312-797X-2018-13-4-287-293

\section{СТЕЛЬНОСТЬ-АССОЦИИРОВАННЫЕ КОНЦЕНТРАЦИИ ГЛИКОПРОТЕИНА У НЕСТЕЛЬНЫХ КОРОВ}

\author{
A. $\operatorname{Ayad}^{1}$, K. Touati ${ }^{2}$ \\ ${ }^{1}$ University of Bejaia \\ Bejaia, 06000, Algeria \\ ${ }^{2}$ University of Liege \\ Liege, 4000, Belgium \\ hanine06@gmail.com
}

Целью настоящей работы было сравнительное описание трех вариантов измерения концентрации bPAGc использованием трех систем RIA в послеродовом периоде у нестельных коров. Три коровы голштинско-фризской породы смешанного возраста были диагностированы как нестельные. Образцы крови отбирались из хвостовой артерии в пробирки, с покрытием EDTA. Образцы собирали каждые 2 дня в 2-месячный стойловый период в отсутствии быков. Плазму получали центрифугированием сразу после сбора и хранили до начала анализа при температуре $-20{ }^{\circ} \mathrm{C}$. Концентрацию PAG в плазме измеряли с помощью радиоиммунологического анализа с некоторыми изменениями. B RIA-780 и RIA-809 наблюдался высокий пик концентрации PAG, достигающий 2,56 нг/мл и 0,89 нг/мл соответственно. Эти пики продолжались более 3 дней (два последовательных образца были положительными). Другие системы RIA показывали концентрацию PAG ниже минимальной границы для периода стельности (> 0,8 нг/мл) и всегда оставались такими. Наши данные ясно показывают, что есть другой источник экспрессии гликопротеинов (например, яичники), кроме плаценты у коровы. Настоящее исследование могло бы стать предметом для будущих более масштабных исследований по этому же вопросу, основываясь на более глубоком изучении других структурных элементов плаценты.

Ключевые слова: ПАГ, радиоиммунологический анализ, нестельная, корова 